\title{
Peran Mediasi Orang Tua dan Anonimitas terhadap Kecenderungan Cyberbullying Siswa
}

\section{The Role of Parents' Mediation and Anonimity on Cyberbullying Intentions at High School Students}

\author{
Fauzan Heru Santhoso ${ }^{1}$ \\ Fakultas Psikologi, Universitas Gadjah Mada
}

\begin{abstract}
This study aimed to determine the role of parental mediation and anonymity towards the tendency of cyberbullying behavior of high school students. This research needs to be done because the tendency of cyberbullying among students is increasing lately. In this study parental mediation and anonymity were predicted to have an influence on cyberbullying tendencies. Therefore the hypothesis in this study was the parental mediation and anonymity can predict cyberbullying tendencies of high school students. The subjects of the study were 159 students of grade XI of state and private high schools in Yogyakarta, with age ranging from 15 to 19 years old, the research subjects were obtained by purposive sampling. Three scales were used in this study, namely the parent mediation scale, the anonymity scale, and the cyberbullying scale. Data analysis used was multiple regression. The results showed that parental mediation and the perception of anonymity had a role in cyberbullying behavior $(F=10.264 ; d f=2.156 ; p<0.01)$. The effective contribution of the two independent variables to the dependent variable was $11.6 \%$ with parent mediation variable contributing $5.83 \%$ and the perception variable contributing $5.78 \%$ to anonymity.
\end{abstract}

Keywords: anonymity; cyberbullying; parent mediation

Abstrak. Penelitian ini bertujuan untuk mengetahui peran mediasi orang tua dan anonimitas terhadap kecenderungan perilaku cyberbullying pelajar SMA. Penelitian ini perlu dilakukan karena kecenderungan cyberbullying pelajar akhir-akhir ini semakin meningkat. Hipotesis dalam penelitian ini ialah mediasi orang tua dan anonimitas dapat memprediksi kecenderungan cyberbullying pelajar SMA. Subjek penelitian adalah siswa kelas XI SMA Negeri dan Swasta yang ada di Yogyakarta sebanyak 159 siswa, rentang usia antara 15 sampai dengan 19 tahun, diperoleh dengan purposive sampling. Tiga buah skala digunakan dalam penelitian ini yaitu skala mediasi orang tua, skala anonimitas, dan skala cyberbullying. Analisis data menggunakan regresi berganda. Hasil penelitian menunjukkan bahwa mediasi orang tua dan persepsi anonimitas memiliki peran terhadap perilaku cyberbullying $(F=10,264 ; d f=2,156$; $p<0,01)$. Sumbangan efektif kedua prediktor terhadap kriteria sebesar $11,6 \%$, variabel mediasi orang tua menyumbang 5,83\% dan variabel persepsi terhadap anonimitas sebesar 5,78\%.

Kata kunci: anonimitas; cyberbullying; mediasi orang tua

Kowalski (2014) menjelaskan cyberbullying didefinisikan sebagai agresi yang dilakukan dengan sengaja dan berulang dilaku-

\footnotetext{
${ }^{1}$ Korespondensi mengenai artikel ini dapat melalui: fauzan@ugm.ac.id
}

kan dengan menggunakan media elektronik (misal: email, blog, pesan instan, pesan teks) terhadap seseorang yang tidak dapat dengan mudah membela dirinya. Beberapa penelitian dengan tema cyber- 
bullying menunjukkan bahwa 20\% remaja pernah terlibat dalam aktivitas cyberbullying (Shin \& Ahn, 2015). Penelitian di Turki menunjukkan bahwa 149 (35,7\%) dari remaja pernah menjadi korban bullying melalui media setidaknya sekali (Beyazit, Simsek, \& Ahyan, 2013). Survei yang dilakukan di Inggris pada tahun 2002 menunjukkan bahwa satu dari empat remaja usia 11-19 tahun telah dianiaya di dunia maya (National-Children-Home, 2002). Demikian juga dengan di Kanada seorang bocah berusia 15 tahun merasa dipermalukan oleh teman-teman sekolahnya dan putus sekolah setelah ia membuat video meniru adegan pertarungan dalam film perang bintang dan dibagikan temantemannya melalui internet (Snider \& Borel, dalam Li, 2005). Penelitian di Amerika yang dilakukan beberapa ahli menunjukkan bahwa cyberbullying akan meningkatkan resiko negatif secara psikososial, yaitu harga diri yang menurun, kecenderungan bunuh diri, menurunnya performa di sekolah, depresi, dan lain sebagainya (Goldstein, 2015).

Kecenderungan cyberbullying di Indonesia saat ini, baik di sekolah dasar maupun menengah, semakin sering terjadi. Hal ini disebabkan antara lain karena semakin mudahnya mengakses internet dan semakin maraknya penggunaan telepon pintar (smartphone) di antara mereka. Kemudahan yang diperoleh karena kemajuan teknologi komunikasi tidak hanya memberikan dampak positif bagi penggunanya, tapi kadang-kadang menimbulkan dampak negatif, salah satunya adalah untuk "mem-bully" temannya. Sartana dan Afriyeni dalam studinya pada siswa di Padang menemukan bahwa terdapat $78,0 \%$ siswa yang mengaku pernah melihat cyberbullying, 21,0\% siswa pernah menjadi pelaku, dan $49,0 \%$ siswa pernah menjadi korban (Sartana \& Afriyeni, 2017).

Sementara itu, hasil penelitian Safaria pada tahun 2016 juga menunjukkan bahwa 80 persen siswa (total 102 siswa) dalam penelitiannya telah sering mengalami cyberbullying, dan cyberbullying dianggap sebagai peristiwa kehidupan yang penuh stres (Malihah dan Alfiasari, 2018). Survei Ipsos di Indonesia, menunjukkan $14 \%$ orang tua yang menjadi responden survei menyatakan bahwa anak mereka pernah mengalami cyberbullying, dan 53\% menyatakan mengetahui bahwa anak mereka di komunitasnya pernah mengalami cyberbullying (Gottfried, 2012).

Hasil observasi yang dilakukan di Kota Yogyakarta terhadap beberapa akun media sosial siswa SMA/MA/SMK secara acak, ditemukan sebanyak 20 akun aktif di media sosial Facebook dan Line. Selanjutnya hasil temuan menunjukkan sebanyak 13 dari 20 orang siswa (65\%) melakukan cyberbullying (Larasati \& Fitria, 2016). Oleh sebab itu Cyberbullying dapat berarti pula kesalahan penggunaan teknologi informasi untuk menyakiti dan melecehkan orang lain dengan sengaja secara berulang-ulang. Cyberbullying dapat terjadi pada kelompok orang yang saling mengenal maupun kelompok yang tidak saling mengenal. Cyberbullying dapat menyebabkan pelaku menggunakan identitas palsu yang menyebabkan pelaku merasa bebas dari aturan-aturan sosial dan normatif yang ada. Cyberbullying dapat terjadi di hampir semua media sosial seperti Facebook, Myspace, dan Twitter (Smith et. al., 2008).

Cyberbullying merupakan kelanjutan dari perilaku bullying. Cyberbullying dari segi tindakannya lebih aman daripada bullying, karena cyberbullying dalam eksekusinya dilakukan melalui media perangkat elektronik dan tidak face to face. 
Smith, et al. (2008) memberi definisi cyberbullying adalah tindakan agresif yang dilakukan dengan menggunakan perangkat elektronik oleh individu atau kelompok secara berulang terhadap korban yang tidak berdaya membela dirinya. Kowalski (2014) menjelaskan cyberbullying sebagai agresi yang dilakukan dengan sengaja dan berulang dilakukan dengan menggunakan media elektronik (misal: email, blogs, pesan instan, pesan teks) terhadap seseorang yang tidak dapat dengan mudah membela dirinya. Dapat disimpulkan bahwa cyberbullying adalah agresi secara verbal yang dilakukan melalui media elektronik (hp, laptop, pc, dll) terhadap individu atau kelompok secara berulang dan individu/kelompok tersebut tidak berdaya untuk membela diri. Tujuan dari perilaku cyberbullying ialah mengancam, mempermalukan, atau mengintimidasi korban yang tidak dengan mudah membela dirinya sendiri dan perilaku agresif ini dilakukan dengan menggunakan ponsel, e-mail, chatting online, serta ruang online seperti Facebook, Messenger, atau blog pribadi (Li., 2005). Oleh sebab itu ada beberapa aspek-aspek cyberbullying, yaitu aspek pengulangan (repetition), aspek ketidakseimbangan kekuatan (power imbalance), aspek kesengajaan (intention), dan aspek agresi (aggressive).

Ada beberapa faktor yang mendorong terjadinya cyberbullying yang dilakukan melalui media sosial/massa, yaitu strain atau adanya ketegangan psikis karena adanya hubungan yang negatif dengan orang lain, persepsi terhadap korban yang "layak" di-bully, peran orang tua dalam mengawasi anaknya berinteraksi di dunia maya, dan karakteristik kepribadian pelaku cyberbullying (Pratiwi, 2011). LeBlanc (2012) menyatakan perasaan tidak aman pada korban cyberbullying lebih parah dibandingkan dengan bully yang terjadi di dunia nyata. Bully yang terjadi di dunia nyata, korban merasa aman ketika sudah sampai di rumah, tapi korban cyberbullying merasa terancam terus menerus. Disa (2011) menyatakan ada beberapa faktor penyebab terjadinya cyberbullying di antaranya adalah bullying tradisional, karakteristik kepribadian, persepsi terhadap korban, strain, serta peran interaksi orang tua dan anak (mediasi orang tua).

Mediasi orang tua adalah strategi yang digunakan oleh orang tua untuk mengatur penggunaan media oleh anak (Livingstone dan Helsper, 2008). Mediasi orang tua juga diartikan sebagai usaha orang tua untuk mengurangi efek negatif media pada anak-anak di mana orang tua mengambil peran aktif dalam mengatur dan meregulasi pengalaman anak dengan media (Clark, 2011). Dapat disimpulkan bahwa mediasi orang tua ialah strategi yang digunakan oleh orang tua untuk mengatur dan mengurangi efek negatif media. Selanjutnya dikatakan bahwa mediasi orang tua terdiri dari berbagai bentuk manajemen, dikategorikan sebagai berikut: 1) mediasi terbatas yang mencakup strategi orang tua untuk mengontrol situs web yang dikunjungi atau perangkat lunak yang dipasang oleh anak-anak, dan penggunaan perangkat elektronik yang membatasi konten dan situs web yang dikunjungi; 2) mediasi evaluatif berkaitan dengan penciptaan aturan bersama tentang informasi pribadi yang tidak boleh dibagikan oleh anak-anak, pada jumlah waktu yang dihabiskan untuk penggunaan Internet, dan situs web yang dapat atau tidak dapat dikunjungi; dan 3) penggunaan bersama yaitu partisipasi aktif orang tua saat anak-anak online, memberi saran dan membantu tentang penggunaan Internet, merekomendasikan situs web atau berpartisipasi dalam aktivitas online dengan anak-anak (Lee \& 
Chae, 2007). Mediasi orang tua dengan anak dalam mengakses internet menurut Navarro, Serna, Martínez, \& Oliva (2013) terdapat tiga bentuk mediasi, yaitu: Mediasi Restriktif (Orang tua saya mengecek web yang saya buka di internet); Mediasi Evaluatif (Orang tua dan saya punya kesepakatan lamanya menggunakan internet); dan Mediasi Co-using (Orang tua membantu dan memberikan saran dalam penggunaan internet).

Sebuah studi Kanada baru-baru ini oleh Dr. John Leblanc meninjau 41 kematian remaja dari Kanada, AS, Australia, dan Inggris menemukan bahwa $78 \%$ dari remaja akan bunuh diri karena di-bully di sekolah serta menunjukkan bahwa anonimitas dapat mendorong terjadinya cyberbullying (LeBlanc, 2012). Anonimitas, yang meningkatkan disinhibisi, dapat mengarah ke agresi karena pelaku mungkin merasa di luar jangkauan pengguna internet, selain itu orang mempunyai kemampuan untuk bersembunyi di balik nama layar palsu, atau menggunakan nama layar orang lain (Ferrara, et al, 2018).

Wallace (2008) menjelaskan anonimitas sebagai suatu "bentuk tidak teridentifikasi" dan "tidak dikenal"-nya keberadaan seseorang. Scott (2005) menyatakan anonimitas dapat dijelaskan sebagai sejauh mana identitas sumber pesan tidak diketahui, dengan demikian semakin sedikit pengetahuan yang dimiliki seseorang sumber dan semakin sulit untuk menentukan siapa sumbernya adalah salah satu cara untuk mengetahui anonimitas seseorang. Pinsonneault dan Heppel (Hite, Voelker, \& Robertson, 2014) mendefinisikan anonimitas sebagai ketidakmampuan anggota kelompok untuk mengidentifikasi asal pesan yang mereka terima dan tujuan pesan yang mereka kirim. Dari beberapa pengertian anonimitas di atas, maka dapat disimpulkan anonimitas ialah tidak dike- nalnya identitas seseorang dalam melakukan interaksi sosial di media. Pengertian anonimitas dan deindividuasi sering digunakan secara bergantian dalam dunia pengetahuan (Lightdale \& Prentice, dalam Geen \& Donerstein, 1998). Zimbardo (dalam Hite, et al. 2014) menyatakan bahwa deindividuasi adalah kondisi psikologis penurunan evaluasi diri yang menyebabkan perilaku anti-normatif dan disinhibited perilaku. Selanjutnya dikatakan oleh Solomon, et al. (dalam Hite, et al. 2014) bahwa subjek yang tidak dikenal (anonim) kurang dapat menunjukkan keinginan untuk membantu orang lain dibandingkan subjek yang tidak anonim, dan subjek anonim memiliki kecenderungan untuk melanggar norma-norma. Hal ini dibuktikan dengan penelitian yang dilakukan Barlett yang hasil penelitiannya menunjukkan anonimitas dan perilaku cyberbullying terbukti dapat meramalkan perilaku cyberbullying selanjutnya dari seseorang (Barlett, 2015).

Dalam penelitiannya Wright (2015) menemukan bahwa hubungan antara viktimisasi cyberbullying dan depresi, serta viktimisasi cyberbullying dan kecemasan, lebih lemah ketika ada mediasi orang tua, hal ini menunjukkan bahwa mediasi orang tua memiliki kekuatan untuk menangkal efek negatif yang terkait dengan masalah cyberbullying. Kondisi yang anonim juga berpengaruh terhadap intensitas untuk "melukai" orang lain, seperti ditunjukkan oleh hasil penelitian Silke (2003) yaitu: Ada hubungan yang positif antara penyerang yang tidak dikenal (anonim) dengan agresivitas. Semakin tidak jelas identitas penyerang, maka semakin parah luka fisiknya, lebih banyak melukai orang, lebih sering melakukan vandalisme, dan lebih suka melakukan ancaman terhadap korban yang baru diserang. Demikian juga dengan hasil penelitian Goldstein (2015) 
tentang hubungan teman sebaya secara offline dan perilaku sosial menunjukkan bahwa remaja yang mengungkapkan lebih banyak tentang pengalaman mereka kepada orang tua mereka memiliki masalah perilaku dan tingkat agresi yang rendah.

Penelitian ini bertujuan untuk mengetahui peran mediasi orang tua dan persepsi anonimitas terhadap kecenderungan cyberbullying pelajar SMA di Yogyakarta. Kedua variabel tersebut dari beberapa penelitian yang ada menunjukkan memiliki pengaruh yang signifikan terhadap cyberbullying. Penelitian tersebut antara lain penelitian tentang pengaruh mediasi yang dilakukan oleh orang tua pernah dilakukan oleh Beyazit, et al. (2017) hasil penelitiannya menunjukkan bahwa remaja di Turki yang memiliki komputer sendiri, kontrol orang tua dalam penggunaan internet, dan pengalaman pernah mengalami bully di internet adalah prediktor cyberbullying yang signifikan. Penelitian lain dengan judul Pengaruh Self-esteem dan Pola asuh Orang tua Terhadap Perilaku Cyberbullying pada Siswa MAN 1 Tangerang (Akbar, 2015) hasilnya menunjukkan bahwa Self-esteem dan Pola asuh Orang tua memengaruhi perilaku cyberbullying. Demikian juga penelitian tentang anonimitas hubungannya dengan agresivitas dilakukan oleh Silke (2003) yang berjudul Deindividuation, Anonimity, and Violence: Findings from Northern Ireland menunjukkan bahwa ada hubungan positif yang signifikan antara agresor yang disamarkan dengan tingkah laku agresifnya, atau dengan perkataan lain semakin agresor disamarkan (anonim), maka perilaku agresifnya semakin tinggi. Dengan demikian semakin seseorang disamarkan identitasnya (anonim), maka keinginan untuk berbuat agresif (bully) semakin kuat. Anonimitas menurut Moore, Nakano, Enomoto, \&
Suda (2012) dapat mengakibatkan cyberbully lebih 'keras dan menyakitkan' (Li, 2007) atau 'agresi tinggi' dan perilaku yang tidak pantas '(Ybarra \& Mitchell, 2004). Anonimitas juga memberikan ketidakseimbangan kekuatan pada dunia maya yang membatasi kemampuan korban untuk mencegah perilaku agresif (David-Ferdon \& Hertz, 2007).

Kasus tentang cyberbullying di kota Yogyakarta pernah diteliti oleh Pusat Studi Islam, Universitas Islam Indonesia (PSI UII) Yogyakarta pada tahun 2012 yang menunjukkan bahwa siswa di lima Sekolah Menengah Atas (SMA) di Yogyakarta dan Jawa Tengah 91 persen memiliki pengalaman cyberbullying, 77 persen diantaranya disebabkan karena faktor kurangnya perhatian orang tua. Cyberbullying merupakan fenomena gunung es yang harus segera ditangani karena akibat dari cyberbullying sangat merugikan para pelajar yaitu mengalami depresi (Sari \& Suryanto, 2016). Mediasi orang tua dan anonimitas digunakan sebagai prediktor, karena dari beberapa penelitian yang sudah dilakukan dua variabel tersebut memiliki peran yang cukup besar munculnya cyberbullying (Shin \& Li, 2017; Moore., Nakano, Enomoto, \& Suda, 2012; Christie \& Dill, 2016). Berdasarkan uraian di atas, maka rumusan masalah yang diajukan dalam penelitian ini ialah: apakah mediasi orang tua dan anonimitas memiliki peran yang signifikan munculnya cyberbullying?

\section{Metode}

Penelitian ini mengkaji tiga variabel, yaitu mediasi orang tua (parents' mediation), persepsi anonimitas (perceived anonymity), dan kecenderungan perilaku cyberbullying. Variabel mediasi orang tua dan persepsi anonimitas sebagai variabel prediktor. 
Variabel perilaku cyberbullying sebagai variabel kriterium.

Subjek dalam penelitian ini ialah siswa kelas XI SMA Negeri atau Swasta. Jumlah subjek sebesar 159 siswa (41\% lakilaki dan 59\% perempuan). Subjek yang berasal dari SMA Negeri sebesar $60 \%$ dan Swasta sebesar $40 \%$. Rentang usia subjek meliputi 15 tahun (19\%), 16 tahun (57\%), 17 tahun (23\%), 18 tahun (5\%), dan 19 tahun $(1 \%)$.

Instrumen yang digunakan dalam penelitian ini meliputi Skala Mediasi Orang Tua, Skala Persepsi Anonimitas, dan Skala Perilaku Cyberbullying. Untuk mengukur perilaku cyberbullying, menggunakan instrumen penelitian yang dibuat oleh Sinaga (2016). Instrumen ini didasari pada aspek-aspek perilaku cyberbullying yang meliputi aspek pengulangan (repetition), aspek ketidakseimbangan kekuatan (power inbalance), aspek kesengajaan (intention), dan aspek agresi (aggressive). Skala Perilaku Cyberbullying memiliki koefisien reliabilitas Alpha sebesar 0,918. Selain itu, butir-butir dalam skala ini memiliki nilai korelasi butir-total yang berkisar 0,367 - 0,688. Skala Mediasi Orang Tua, disusun peneliti berdasarkan teori Navarro, et al. (2013). Proses validasi alat ukur mediasi orang tua dengan analisis faktor eksplorasi dengan rotasi Oblimin dilakukan pada sembilan aitem. Hasilnya nilai The Kaiser-Meyer-Okling sebesar 0,85, dan hasil tes Bartlett's Test of Sphericity signifikan $(\mathrm{p}<0,01)$. Hasil ini menunjukkan bahwa faktor-faktor tersebut mendukung aitemnya. Koefisien reliabilitas Alpha pada instrumen ini sebesar 0,924 . Setiap butir memiliki nilai korelasi butir-total berkisar antara 0,348 0,628 . Untuk instrumen pengukuran persepsi anonimitas, peneliti mengadaptasi instrumen yang dibuat oleh Hite, et al. (2014). Adaptasi perlu dilakukan karena alat ukur tersebut berbahasa Inggris dan pengukuran dilakukan di Inggris. Langkah pertama yang dilakukan adalah menerjemahkan aitem-aitem ke dalam bahasa Indonesia oleh teman dosen dari jurusan bahasa Inggris. Selanjutnya hasil terjemahan itu dibaca oleh beberapa mahasiswa apakah kalimat yang ada di skala itu sudah jelas. Langkah terakhir ialah mengujicobakan skala tersebut kepada sejumlah 103 pelajar di Yogyakarta pada tanggal 9 Agustus 2018. Hasil adaptasi menunjukkan koefisien reliabilitas sebesar 0,731 dengan nilai korelasi butirtotal berkisar 0,368 - 0,543. Teknik analisis yang dilakukan dalam penelitian ini ialah analisis regresi berganda. Analisis ini bertujuan untuk melihat peranan mediasi orang tua dan persepsi anonimitas terhadap perilaku cyberbullying siswa SMA Negeri maupun Swasta di Kota Yogyakarta.

\section{Hasil}

Deskripsi statistik hasil penelitian ini yang meliputi variabel mediasi orang tua, persepsi anonimitas dan perilaku cyberbullying dapat dilihat dalam Tabel 1.

Hipotesis dalam penelitian ini ialah terdapat peran yang signifikan antara

Tabel 1.

Statistik Deskriptif Variabel Mediasi Orang Tua, Persepsi Anonimitas, dan Perilaku Cyberbullying

\begin{tabular}{lcccc}
\hline$N=159$ & Min & Max & Mean & Std. Deviasi \\
\hline Mediasi Orang Tua & 36 & 96 & 64,33 & 12,30 \\
Persepsi Anonimitas & 18 & 52 & 34,10 & 5,90 \\
Perilaku Cyberbullying & 88 & 171 & 136,20 & 16,43 \\
\hline
\end{tabular}


Mediasi Orang Tua dan Persepsi Anonimitas terhadap Perilaku Cyberbullying siswa SMA Negeri maupun Swasta di Kota Yogyakarta. Sebelum melakukan pengujian hipotesis, peneliti melakukan beberapa uji asumsi klasik. Pertama, uji normalitas residu menunjukkan bahwa residu yang muncul dari persamaan regresi memiliki distribusi yang tergolong normal ( $p>0,05)$. Setelah itu, Uji linearitas variabel independen terhadap dependen menunjukkan bahwa variabel mediasi orang tua terhadap perilaku cyberbullying (Linearity $F=10,492 ; d f=1,45 ; p<0,01$ ) dan persepsi anonimitas terhadap perilaku cyberbullying (Linearity $F=8,509 ; d f=1,28$; $p<0,01)$ memiliki hubungan yang linear. Terakhir, Uji Multikolinearitas menunjukkan bahwa tidak terjadi multikolinearitas atau hubungan yang erat antar variabel independen $(\mathrm{VIF}=1.000$; Tolerance $=1.000)$.

Uji hipotesis menggunakan regresi berganda menunjukkan bahwa terdapat peran yang signifikan dari variabel mediasi orang tua dan persepsi anonimitas terhadap perilaku cyberbullying ( $F=10,264$; $d f=2,156 ; p<0,01)$. Sumbangan efektif kedua variabel independen terhadap variabel independen sejumlah 11,6\% dengan masing-masing variabel menyumbang 5,83\% variabel mediasi orang tua dan $5,78 \%$ variabel persepsi anonimitas. Tabel 2 memaparkan peranan masing-masing variabel.

Berdasar Tabel 2., mediasi orang tua memiliki peranan negatif yang signifikan $(t=-3,246 ; p<0,01)$. Di sisi lain, persepsi anonimitas memiliki peranan positif yang signifikan $(t=3,231 ; p<0,01)$. Hal tersebut berarti bahwa variabel persepsi anonimitas dapat meningkatkan perilaku cyberbullying sedangkan mediasi yang dilakukan orang tua dapat menurunkan perilaku cyberbullying siswa.

\section{Diskusi}

Hasil penelitian ini menunjukkan bahwa variabel mediasi orang tua dan persepsi anonimitas memiliki peranan terhadap kecenderungan perilaku cyberbullying. Mediasi orang tua memiliki peranan yang negatif, yaitu berperan dalam menurunkan kecenderungan perilaku cyberbullying yang dilakukan siswa. Hasil ini selaras dengan penelitian yang dilakukan Chang, et al. (2015) yang menunjukkan bahwa mediasi orang tua memiliki hubungan yang negatif dengan perilaku cyberbullying. Atau dengan perkataan lain, semakin orang tua intensif melakukan mediasi dalam penggunaan internet dengan anaknya, maka semakin berkurang kecenderungan anak melakukan cyberbullying terhadap teman-temannya.

Cyberbullying termasuk hal yang menyimpang di mana hal ini merupakan manifestasi dari melemahnya ikatan antara individu dengan lingkungan sosialnya (Petraitis, Flay, \& Miller, 1995). Lingkungan sosial pertama dan terdekat bagi anak ialah keluarga. Melemahnya ikatan anak dengan keluarga akan membuat anak cenderung melakukan perilaku

Tabel 2.

Hasil Uji Parameter Model

\begin{tabular}{llllll}
\hline \multicolumn{1}{c}{ Parameter } & \multicolumn{1}{c}{$\beta$} & $\mathrm{t}$ & \multicolumn{1}{c}{ Sig. } & \multicolumn{1}{c}{$\beta$-Standardized } & Zero Order \\
\hline Konstanta & 83,9 & 8,727 & $\mathrm{p}<0,01$ & - & - \\
Persepsi Anonimitas & 0,677 & 3,231 & $\mathrm{p}<0,01$ & 0,243 & 0,238 \\
Mediasi Orang Tua & $-0,326$ & $-3,246$ & $\mathrm{p}<0,01$ & $-0,244$ & $-0,239$ \\
\hline
\end{tabular}


menyimpang termasuk cyberbullying.

Mediasi orang tua yang tidak berjalan ini dikarenakan hubungan antara orang tua dan anak terganggu. Ennett et al. (2008) mengemukakan bahwa hubungan orang tua dan anak yang terganggu disebabkan oleh ikatan sosial dalam bentuk kedekatan antara orang tua dan anak. Semakin dekat anak dengan orang tua maka orang tua dan anak memiliki kualitas berinteraksi yang baik. Interaksi yang seperti ini memunculkan mediasi orang tua dalam bentuk diskusi, pengawasan, dan aturan bersama.

Selain kedekatan antara orang tua dan anak, konflik yang terjadi dalam keluarga dapat melemahkan ikatan anak dengan keluarganya (Ennett et al., 2008). Dengan adanya konflik di dalam keluarga baik itu mengikutsertakan anak maupun tak mengikutsertakan anak dapat membuat mereka tertekan dan cenderung mencari ikatan lain di luar keluarga. Ketika hal ini terjadi, ikatan sosial anak dengan lingkungan sosial lain lebih kuat, maka peran orang tua dalam melakukan mediasi tidak dapat berjalan. Dengan demikian mediasi tidak dapat dilakukan sehingga anak memiliki kecenderungan besar untuk berperilaku menyimpang.

Ditambah lagi, mediasi orang tua memiliki hubungan negatif dengan perilaku agresif (Nathanson, 1999). Perilaku agresif termasuk perilaku yang menyimpang. Karena perilaku agresif didefinisikan sebagai perilaku baik secara fisik maupun verbal yang dimaksudkan untuk mengganggu orang lain (Myers, 2015). Perilaku mengganggu orang lain seperti mencemooh, menghina, dan perilaku lain memiliki kesamaan dengan bullying. Bullying diartikan sebagai perilaku yang menyakiti orang baik itu secara fisik maupun psikologis yang terjadi secara terus-menerus (Pepler \& Rubin, 1991).
Menyakiti termasuk dalam perilaku mengganggu orang lain atau dengan kata lain sebagai sebuah perilaku agresi. Bahkan perilaku agresif merupakan komponen dari perilaku bullying itu sendiri (Lee, 2009). Dalam konteks penggunaan internet, bullying dalam bentuk ini disebut Cyberbullying yang diartikan sebagai perilaku agresif yang dilakukan secara sengaja dengan menggunakan media elektronik (Kowalski, 2014). Ditekankan kembali bahwa perilaku agresif sangat erat hubungannya dengan perilaku cyberbullying.

Anonimitas menjadi faktor yang meningkatkan perilaku cyberbullying pada siswa. Anonimitas berhubungan erat dengan perilaku agresif (Silke, 2003). Hal ini dikarenakan anonimitas membuat individu tidak teridentifikasi atau tidak dikenali sehingga dengan mudah mereka melakukan perilaku cyberbullying. Individu yang merasa dirinya tidak dikenali atau diidentifikasi dalam media sosial akan merasa tidak bersalah. Perasaan tidak bersalah inilah yang membuat individu akan melakukan perilaku agresif yang jika dilakukan melalui media sosial maka perilaku cyberbullying muncul (Myers, 2015).

Anonimitas dapat meningkatkan perilaku agresif dan bullying dengan berbagai cara. Pertama, dari perspektif social learning theory yang dicetuskan oleh Bandura (1997), anak akan belajar untuk melakukan suatu perilaku berdasar hasil observasi dari orang lain di sekitar mereka yang mereka anggap sebagai contoh diri mereka (model). Ketika anak melihat perilaku bullying yang dilakukan oleh model dalam media sosial dengan tanpa teridentifikasi identitasnya, mereka secara tidak langsung belajar untuk melakukan perilaku tersebut lalu cenderung akan melakukannya. Karena, mereka berpikir 
perilaku tersebut merupakan perilaku yang dicontohkan oleh sosok model mereka.

Kedua, dari perspektif keperilakuan, anak yang melakukan perilaku bullying cenderung merasakan bahwa diri mendapatkan penguatan setelah melakukan perilaku tersebut (Myers, 2015). Ketika anak melakukan perilaku bullying khususnya dalam media sosial, mereka mendapati orang yang mereka bully merasa sedih dan tertekan di mana perilaku mereka lakukan tidak teridentifikasi oleh orang yang menjadi korban dan orang lain. Hal ini membuat anak merasa perilaku agresif dengan tanpa mencantumkan identitas menjadi sebuah perilaku yang menarik untuk dilakukan. Akhirnya, mereka cenderung mengulangi perilaku ini secara terus-menerus.

\section{Kesimpulan}

Kesimpulan penelitian ini ialah terdapat peran yang signifikan variabel mediasi orang tua dan persepsi anonimitas terhadap kecenderungan perilaku cyberbullying siswa SMA Negeri maupun Swasta di Kota Yogyakarta. Adapun masing-masing variabel memiliki peran yang kontradiktif namun kedua variabel memiliki proporsi yang hampir sama. Mediasi orang tua memiliki peran positif yang artinya mediasi orang tua yang baik akan menurunkan perilaku cyberbullying siswa. Di sisi lain, persepsi anonimitas berperan meningkatkan perilaku cyberbullying siswa.

\section{Saran}

Hasil penelitian menunjukkan bahwa mediasi orang tua dan persepsi anonimitas memiliki pengaruh yang signifikan terhadap perilaku cyberbullying. Oleh sebab itu orang tua hendaknya selalu melakukan mediasi penggunaan media sosial pada anak-anaknya agar mereka tidak mudah melakukan cyberbullying kepada orang lain. Demikian juga dengan anonimitas, karena semakin anonim seorang siswa di media sosial semakin besar kecenderungan untuk melakukan bullying. Oleh sebab itu siswa dalam menggunakan media sosial hendaknya menunjukkan identitas sosialnya. Yang dapat dilakukan orang tua yaitu memonitor, mengarahkan, dan mendampingi anak pada saat menggunakan gadget/internet.

Pihak yang berminat untuk melakukan penelitian lebih lanjut dapat mengeksplorasi variabel lain (misal aspek kepribadian) yang tidak dikaji dalam penelitian ini agar pemahaman mengenai cyberbullying dan faktor penyebabnya dapat diperoleh gambaran yang lebih utuh.

\section{Kepustakaan}

Akbar, E. Y. F. R. (2015). Pengaruh selfesteem dan pola asuh orang tua terhadap perilaku cyberbullying siswa MAN 1 Tangerang. Skripsi (tidak dipublikasikan). Jakarta: Fakultas Psikologi UIN Syarif Hidayatullah

Bandura, A. (1997). Self-efficacy: The exercise of control. New York: W.H. Freeman and Company.

Barlett, C. P. (2015). Predicting adolescent's cyberbullying behavior: A longitudinal risk analysis. Journal of Adolescence, 41, 86-95. Diakses tanggal 16 Mei 2018 dari : https://www.sciencedirect.com/s cience/ article/pii/S0140197115000342

Beyazit, U., Simsek, S., \& Ahyan, A. B. (2017). An examintaion of the predictive factors of cyberbullying in adolescents. Social Behavior and Personality, 45(9), 1511-1522. doi: $\underline{10.2224 / \mathrm{sbp} .6267}$ 
Chang, F. C., Chiu, C. H., Miao, N. F., Chen, P. H., Lee, C. M., Chiang, J. T., \& Pan, Y. C. (2015). The relationship between parental mediation and Internet addiction among adolescents, and the association with cyberbullying and depression. Comprehensive Psychiatry, 57, 21-28. doi: 10.1016/ j.comppsych.2014.11.013

Clark, L. S. (2011). Parental mediation theory for the digital age. Communication Theory, 21, 323-343. doi: 10.1111/j.1468-2885.2011.01391.x

Christie, C. \& Dill, E. (2016). Evaluating peers in cyberspace: The impact of anonymity. Computers in Human Behavior, 55, 292-299. Diakses pada tanggal 5 Februari 2017 dari: https://www.sciencedirect.com/science /article/pii/S0747563215301552

David-Ferdon, C. \& Hertz, M. F. (2007). Electronic media, violence, and adolescents: an emerging public health problem. Journal of Adolescent Health, 41(6), S1-S5

Disa, M. (2011). Faktor-faktor yang memengaruhi cyberbullying pada remaja. Paperseminar dan workshop APSIFOR Indonesia, Semarang, Indonesia.

Ennett, S. T., Foshee, V. A., Bauman, K. E., Hussong, A., Cai, L., McNaughton Reyes, H. L., ... DuRant, R. (2008). The social ecology of adolescent alcohol misuse. Child Development, 79(6), 17771791.

Ferrara P., Ianniello, F., Villani, A., \& Corsello, G. (2018). Cyberbullying a modern form of bullying: let's talk about this health and social problem. Italian Journal of Pediatrics, 44(14). Diakses pada 25 Februari 2018 dari: https://ijponline. biomedcentral.com/track/pdf/10.1186/s 13052-018-0446-4

Geen, R. G. \& Donnerstein, E. (1998). Human aggression theories, research, and implications for social policy. Sandiego: Academic Press.

Goldstein, S. E. (2015). Parental regulation of online behavior and cyber aggression: Adolescents' experiences and perspectives. Journal of Psychosocial Research on Cyberspace, 9(4), article 2. Diakses pada 7 April 2017 dari: https://cyberpsy chology.eu/article/view/6097/5919

Gottfried, K. (2012). One in ten (12\%) parents online, around the world say their child has been cyberbullied, 24\% say they know of a child who has experienced same in their community. Diakses pada tanggal 2 November 2018 dari http://www.ipsos-na.com/newspolls/pressrelease.aspx?id $=5462$

Hite, D. M., Voelker, T. \& Robertson, A. (2014). Measuring perceived anonymity: The development of a context independent instrument. Journal of Methods and Measurement in the Social Sciences, 5(1), 22-39. Diakses pada tanggal 25 Maret 2018 dari: https://scholar.google.co.id/scholar?q= Hite,+D.M.,+Voelker,+T.+\%26

+Robertson,+A.++2014.+Measuring+Pe rceived+Anonymity\&hl=id\&as_sdt $=0 \&$ as_vis $=1 \&$ oi $=$ scholart

Kowalski, K. (2014). Watch out cell phones can be addictive. United States: Society for Science \& the Public.

Larasati, A. \& Fitria, M. (2016). Kecenderungan perilaku cyberbullying ditinjau dari traits dalam pendekatan big five personality pada siswa Sekolah Menengah Atas Negeri di Kota Yogyakarta. Jurnal Psikologi Integratif, 5(2), 161-182. Diakses pada 25 Februari 
2018, melalui: http://ejournal.uinsuka.ac.id/isoshum/PI/article/view /1260/1135

LeBlanc, J. C. (2012). Cyberbullying and suicide: A retrospective analysis of 22 cases. Paper presented at the 2012 AAP National Conference and Exhibition.

Lee, E. (2009). The relationship of aggression and bullying to social preference: Differences in gender and types of aggression. International Society for the Study of Behavioral Development, 33(4), 323-330. doi: $\underline{10.1177 / 0165025408098028}$

Lee, S. \& Chae, Y. (2007). Children's Internet use in a family context: Influence on family relationships and parental mediation. CyberPsychology $\mathcal{E}$ Behavior, 10, 640-644.

Li, Q. (2005). New bottle but old wine: A research of cyberbullying in schools. Computers in Human Behavior. 23(4), 1777-1791

Livingstone, S. \& Helsper, E. (2008) Parental mediation of children's Internet use. Journal of Broadcasting $\mathcal{E}$ Electronic Media, 52, 581-599.

Malihah, Z \& Alfiasari. (2018). Perilaku Cyberbullying pada Remaja dan Kaitannya dengan Kontrol Diri dan Komunikasi Orang Tua. Jurnal Ilmu Keluarga dan Konsumen, 11(2), 145-156. Diakses tanggal 2 Maret 2018 pada: https://jurnal.ipb.ac.id /index.php/jikk /article/download/22687/14962

Moore. M. J., Nakano, T., Enomoto, A., \& Suda, T. (2012). Anonymity and roles associated with aggressive posts in an online forum. Computers in Human Behavior, 28, 861-867. Diakses pada tanggal 14 Maret 2017 dari: https://www.sciencedirect.com/science / article/pii/S0747563211002731
Myers, D. G. (2015). Exploring social psychology (Seventh ed). New York: McGraw-Hill Education.

Nathanson, A. I. (1999). Identifying and explaining the relationship between parental mediation and children's aggression. Communication Research, 26(2), 124-143. Diakses pada tanggal 12 Maret 2018 dari: doi: 10.1177/009365099026002002.

National-Children_s-Home (2002). NCH 2002 Survey, 2004-07-15. Diakses pada tanggal 12 Maret 2018 dari: http://www.nch.org.uk/itok/showques tion. asp? faq $=9 \&$ fldAuto $=145$.

Navarro, R., Serna, C., Martínez, V., and Oliva, R. R. (2013). The role of Internet use and parental mediation on cyberbullying victimization among Spanish children from rural public schools. European Journal of Psychology of Education, 28(3), 725-745.

Pepler, D. J., \& Rubin, K. H. (1991). The development and treatment of childhood aggression. Hilsade, NJ: Erlbaum.

Petraitis, J., Flay, B. R., \& Miller, T. Q. (1995). Reviewing theories of adolescent substance use: Organising pieces in the puzzle. Psychological Bulletin, 117(1), 67-86. Diakses pada tanggal 12 Maret 2018 dari: http://www.colorado.edu/ibs/jessor/ps ych7536-805/readings/ petraitis 1995. pdf

Pratiwi, M. D. (2011). Faktor-faktor yang memengaruhi Cyberbullying pada remaja. Paper Seminar dan workshop APSIFOR Indonesia, Semarang, Indonesia.

Sasson, H. \& Mesch, G. (2017). The role of parental mediation and peer norms on the likelihood of cyberbullying. The Journal of Genetic Psychology, 178(1), 1527. doi: 10. 1080/00221325.2016.1195330 
Sari, R. N. \& Suryanto. (2016). Kecerdasan Emosi, Anonimitas, dan Cyberbullying (Bully Dunia Maya). Persona, Jurnal Psikologi Indonesia, 5(1), 48-61.

Sartana \& Afriyeni, N. (2017). Perundungan maya (Cyber Bullying) pada remaja awal. Jurnal Psikologi Insight. 1(1), 25-39. Diakses pada tanggal 22 April 2017 dari: http://ejournal.upi.edu/index.php/insi ght/article/download/8442/5299

Scott, C. R. (2005). Anonymity in applied communication research: Tension between IRBs, researchers, and human subjects. Journal of Applied Communication Research, 33, 242-257.

Shin, N., \& Ahn, H. (2015). Factors affecting adolescents' involvement in cyberbullying: What divides the $20 \%$ from the $80 \%$ ? Cyberpsychology, Behavior, and Social Networking, 18(7), 393 - 399. doi: 10.1089/cyber.2014.0362.

Shin, W. \& Li, B. (2017). Parental mediation of children's digital technology use in Singapore. Journal of Children and Media, 11(1), 1-19. Diakses pada 25 Februari 2018 dari: https://minerva-access.unimelb.edu. au/ bitstream/handle/ 11343/194860/ 2017_JCM.pdf?sequence $=5 \&$ is

Allowed $=\mathrm{y}$

Silke, A. (2003). Deindividuation, anonymity, and violence: Findings from northern ireland. Journal of Social Psychology, 143(4), 493-499. doi: $\underline{10.1080 / 00224540309598458}$

Sinaga, Y. V. (2016). Hubungan antara perilaku asertif dan perilaku cyberbullying di jejaring sosial pada remaja. Skripsi, Tidak diterbitkan. Yogyakarta: Universitas Sanata Dharma.

Smith, P. K., Mahdavi, J., Carvalho, M., Fisher, S., Russel, S., Tippet, N. (2008). Cyberbullying: Its nature and impact in secondary school pupils. Journal of Child Psychology and Psychiatry, 49(4), 376-385. doi: 10.1111/j.1469-7610. 2007. 01846.x.

Wallace, K. (2008). Online anonymity. In K. Himma \& H. Tavani (Eds.), The handbook or information and computer ethics. New York: Wiley.

Wright, M. F. (2015). Cyber victimization and perceived stress: linkages to late adolescents' cyber aggression and psychological functioning. Youth $\mathcal{E}$ Society, 47(6) 789-810. doi: $\underline{10.1177 / 0044118 X 14537088}$

Ybarra, M. L. \& Mitchell, K. J. (2004). Youth engaging in online harassment: associations with caregiver-child relationships, internet use, and personal characteristics. Journal of Adolescence, 27(3), 319-336. 